Article

\title{
Antiarthritic Effects of a Root Extract from Harpagophytum procumbens DC: Novel Insights into the Molecular Mechanisms and Possible Bioactive Phytochemicals
}

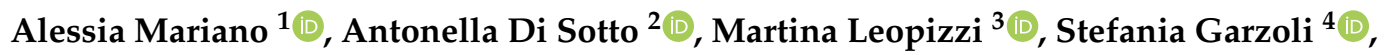 \\ Valeria Di Maio ${ }^{3}$, Marco Gulli ${ }^{2}$, Pietro Dalla Vedova ${ }^{5}$, Sergio Ammendola ${ }^{6}$ and \\ Anna Scotto d'Abusco 1,*(i) \\ 1 Department of Biochemical Sciences, Sapienza University of Roma, P.le Aldo Moro 5, 00185 Roma, Italy; \\ alessia.mariano@uniroma1.it \\ 2 Department of Physiology and Pharmacology, Sapienza University of Rome, P.le Aldo Moro 5, 00185 Rome, \\ Italy; antonella.disotto@uniroma1.it (A.D.S.); marco.gulli@uniroma1.it (M.G.) \\ 3 Department of Medico-Surgical Sciences and Biotechnologies, Polo Pontino-Sapienza University, \\ 04100 Latina, Italy; martina.leopizzi@uniroma1.it (M.L.); dimaiovaleria@libero.it (V.D.M.) \\ 4 Department of Drug Chemistry and Technologies, Sapienza University of Rome, P.le Aldo Moro 5, \\ 00185 Rome, Italy; stefania.garzoli@uniroma1.it \\ 5 UOC di Ortopedia e Traumatologia, Ospedale Santa Scolastica di Cassino, ASL di Frosinone, Via S. Pasquale, \\ 03043 Cassino, Italy; pietro.dallavedova@aslfrosinone.it \\ 6 Ambiotec S.A.S. Via Appia Nord 47, 04012 Cisterna di Latina (LT), Italy; ambiotec@libero.it \\ * Correspondence: anna.scottodabusco@uniroma1.it; Tel.: +39-06-4991-0947
}

Received: 28 July 2020; Accepted: 21 August 2020; Published: 23 August 2020

\begin{abstract}
Harpagophytum procumbens (Burch.) DC. ex Meisn. is a traditional remedy for osteoarticular diseases, including osteoarthritis (OA), although the bioactive constituents and mechanisms involved are yet to be clarified. In the present study, an aqueous $H$. procumbens root extract (HPE; containing $1.2 \%$ harpagoside) was characterized for its effects on synoviocytes from OA patients and phytochemical composition in polyphenols, and volatile compounds were detected. HPE powder was dissolved in different solvents, including deionized water $\left(\mathrm{HPE}_{\mathrm{H} 2 \mathrm{O}}\right)$, DMSO $\left(\mathrm{HPE}_{\mathrm{DMSO}}\right), 100 \% v / v$ ethanol $\left(\mathrm{HPE}_{\mathrm{EtOH} 100}\right)$, and $50 \% v / v$ ethanol ( $\left.\mathrm{HPE}_{\mathrm{EtOH} 50}\right)$. The highest polyphenol levels were found in $\mathrm{HPE}_{\mathrm{DMSO}}$ and $\mathrm{HPE}_{\mathrm{EtOH} 50}$, whereas different volatile compounds, mainly $\beta$-caryophyllene and eugenol, were detected in all the extracts except for $\mathrm{HPE}_{\mathrm{H} 2 \mathrm{O}}$. $\mathrm{HPE}_{\mathrm{H} 2 \mathrm{O}}$ and $\mathrm{HPE}_{\mathrm{DMSO}}$ were able to enhance CB2 receptor expression and to downregulate PI-PLC $\beta 2$ in synovial membranes; moreover, all the extracts inhibited FAAH activity. The present results highlight for the first time a multitarget modulation of the endocannabinoid system by HPE, likely ascribable to its hydrosoluble compounds, along with the presence of volatile compounds in H. procumbens root. Although hydrosoluble compounds seem to be mainly responsible for endocannabinoid modulation by HPE, a possible contribution of volatile compounds can be suggested, strengthening the hypothesis that the entire phytocomplex can contribute to the H. procumbens healing properties.
\end{abstract}

Keywords: osteoarthritis; nutraceuticals; polyphenols; volatile compounds; $\beta$-caryophyllene; eugenol; FAAH; cannabinoid receptors; phospholipases

\section{Introduction}

Osteoarthritis (OA) is a pathology of the whole joint structure, involving several cellular and molecular processes, in different types of cells, such as chondrocytes, osteoblasts, synoviocytes, and 
immune cells [1]. The clinical symptoms include pain as well as joint dysfunction and deformity, often leading to joint replacement surgery, with high costs for healthcare [2].

Recently, an association between inflammation and endocannabinoid receptors has been described [3]. In particular, the role of $\mathrm{CB} 2$ receptors seems very interesting in OA inflammation. CB2 is a peripheral cannabinoid receptor and has been found in immune system cells, raising the possibility that the endocannabinoid system could have a role in immunomodulatory processes [3]. In this respect, several studies reported that mice lacking CB2 receptors showed an exacerbated inflammatory phenotype [4]. Moreover, CB2 receptors are involved also in inhibiting nociceptive transmission [5]. CB2 receptor signaling has been associated with phospholipase C (PI-PLC) activation in calf pulmonary endothelial cells and in mast cells [6,7]. Moreover, the inhibition of inflammatory pathways, such as NF-KB nuclear translocation, has been obtained by inhibiting the PI-PLC $\beta$ pathway in osteoblast-like cells [8]. The presence of CB2 in articular joints has been explored, mainly in animal models, and it has been highlighted in chondrocytes and in synoviocytes $[9,10]$. Thus, therapeutic strategies able to modulate CB2 signaling could be considered as a novel approach.

$\mathrm{OA}$ is treated with analgesic agents and anti-inflammatory and painkiller drugs, mainly non-steroidal anti-inflammatory drugs (NSAIDs), with the aim of alleviating symptoms [11]. Structure-modifying agents, such as nutraceuticals, are also administered to OA patients, with the aim of preventing or delaying cartilage degradation, even though further studies are required to confirm their effectiveness [12-14]. ARTRIT DOL, an Italian food supplement (Italian Minister of Health food supplement no. 71362 since 2013), is a composition containing glucosamine, chondroitin sulfate, extracts from Harpagophytum procumbens DC. and Glycyrrhiza glabra L., Curcuma longa L. roots, manganese, and copper in traces. Although this work does not focus on ARTRIT DOL, it is interesting to note that, as stated by the manufacturer, this nutritional supplement obtained good feedback from OA patients, in particular for the reduction of pain.

Harpagophytum procumbens (Burch.) DC. ex Meisn. (Fam. Pedaliaceae), commonly known as devil's claw, is a plant used worldwide as a traditional remedy for joint pain associated with OA and mild rheumatic ailments $[15,16]$. Moreover, it has been described to have analgesic effects on neuropathic pain in rats [17]. The harpagoside, one of the characteristic constituents of H. procumbens root, has been shown to be effective for osteoarthritis and low back pain [18].

The pharmacological activity of devil's claw root is attributed to the whole phytocomplex containing iridoid glucosides, such as harpagoside, phenolic glycosides (acteoside and isoacteoside), mono- and polysaccharides, triterpenes (mainly oleanolic acid, $3 \beta$-acetyloleanolic acid, and ursolic acid), phytosterols, phenolic acids (caffeic, cinnamic, and chlorogenic acids), flavonoids, and minor components such as volatile compounds [15]. A number of studies have been conducted in order to characterize the analgesic and anti-inflammatory activities of $H$. procumbens and its secondary metabolites. An in vitro study showed that $H$. procumbens was able to decrease the production of proinflammatory cytokines and inhibit metalloprotease activity in human monocytes [19]. Studies conducted in animals showed that an aqueous H. procumbens extract showed dose-dependent analgesic and anti-inflammatory activity, but the purified harpagoside did not effectively inhibit the inflammatory pathways, at least at the dosage used in that study [20]. However, human clinical studies showed that the administration of $H$. procumbens root extract was able to improve the clinical picture of OA patients, in terms of pain and limitation of movements [21-23], suggesting that the phytocomplex may contribute to observed effects [20]. The biological effects of volatile compounds have not been extensively studied. Recently, the combination of purified $\beta$-caryophyllene with curcumin was shown to reduce the inflammation pathway through inhibition of NF- $\mathrm{kB}$ in OA primary chondrocytes [24]. Purified $\beta$-caryophyllene has been described to mitigate pain in a mouse model of arthritis through a mechanism involving CB2 receptors [25]. Moreover, the volatile eugenol, a known dentistry analgesic, has been shown to be effective in a monoiodoacetate-induced rat model of osteoarthritis [26].

In the present study, an $H$. procumbens root extract was studied for its effects on human primary synoviocytes, with particular attention to the expression of CB2 receptors; furthermore, the extract was 
characterized for its polyphenol and volatile phytochemical content, in order to highlight possible novel bioactive compounds.

\section{Materials and Methods}

\subsection{Harpagophytum Procumbens Extract}

The dry aqueous extract from H. procumbens root (HPE) was provided by Ambiotec S.A.S. It was obtained starting from $300 \mathrm{~g}$ of root slices, which were repeatedly washed with cold ethanol $99 \%(v / v)$. After being washed, the slices were reduced by grinding with an electric miller for $10 \mathrm{~min}$, and the powder was recovered by a sieve, with $4 \mathrm{~mm}$ holes. This powder was dissolved in ethanol/water solution $(1: 5 w / v)$ in the dark, shaking at $58{ }^{\circ} \mathrm{C}$ for $24 \mathrm{~h}$, and then, it was filtered using $0.45 \mu \mathrm{m}$ membrane. The retained fraction was air dried at $80{ }^{\circ} \mathrm{C}$ in a static dryer and in the presence of $5 \%$ maltodextrin (as carrier). The powder was again screened by a certified sieve (diameter $200 \mu \mathrm{m}$, mesh 100; net light $0.150 \mu \mathrm{m}$ ). The final yield of this preparation was 70\% (drug-extract ratio, DER 1.4) of the initial root slices. The extract was a fine brown-colored powder with characteristic smell and taste, containing $1.2 \%(w / w)$ harpagoside. The powder was stored at room temperature in dry and dark conditions until use.

In order to evaluate antiarthritic activity and to highlight possible bioactive constituents, HPE was further dissolved in different solvents, including dimethyl sulfoxide (DMSO), 100\% v/v ethanol (EtOH), $50 \% v / v \mathrm{EtOH}$, and deionized water. These solvents were chosen on the basis of their biocompatibility and ability to dissolve different classes of phytochemicals, mainly focusing on volatile compounds and polyphenols. Particularly, DMSO possesses high solubilizing properties for both polar and nonpolar compounds, thus, being able to dissolve the entire phytocomplex. Conversely, deionized water and ethanol recover mainly polar and nonpolar molecules, respectively, whereas $50 \% v / v$ ethanol is able to collect compounds dissolved by both solvents.

\subsection{Phytochemical Analysis}

\subsubsection{Determination of Total Polyphenols, Tannins, and Flavonoids}

Total amounts of polyphenols and tannins in the tested extracts were determined spectrophotometrically by the Folin-Ciocalteu method, as previously reported [27]. For both polyphenols and tannins, the absorbance was measured at $765 \mathrm{~nm}$, and the amount was calculated as tannic acid equivalent (TAE) per milligram of dry HPE extract. Furthermore, total flavonoids and its subclass flavonols were measured by applying the aluminum chloride method with minor changes [27]. Specifically, total flavonoids were measured after mixing equal volumes of each extract $(2 \mathrm{mg} / \mathrm{mL})$ and aluminum trichloride ( $2 \% w / v$ in methanol), whereas the content of flavonols was determined by mixing $50 \mu \mathrm{L}$ extract $(4 \mathrm{mg} / \mathrm{mL}), 20 \mu \mathrm{L}$ aluminum trichloride (10\% $w / v$ in methanol), $60 \mu \mathrm{L}$ sodium hydroxide $(1 \mathrm{M}), 10 \mu \mathrm{L}$ sodium nitrite $(5 \% w / v$ in deionized water), and $70 \mu \mathrm{L}$ deionized water. After a 10-min incubation, the absorbance was measured at $415 \mathrm{~nm}$, and the total contents of flavonoids and flavonols were determined and expressed as quercetin equivalent $(\mathrm{QE})$ per milligram of dry HPE extract.

\subsubsection{Solid-Phase Microextraction (SPME)}

For the extraction of volatile compounds, solid-phase microextraction (SPME) holders and coating fibers (Supelco; Bellefonte, PA, USA) were used. The sampling was performed with an SPME fiber (50/30 $\mu \mathrm{m}$ divinylbenzene/carboxen/polydimethylsiloxane-DVB/CAR/PDMS). Before sampling, the SPME fiber was conditioned by heating in the injector of a gas chromatograph at $270{ }^{\circ} \mathrm{C}$ for $30 \mathrm{~min}$ in order to remove traces of contaminants. Prior to analysis, a fiber blank was run to confirm the absence of contaminant peaks. To obtain a better extraction, SPME conditions, such as the most suitable temperature and equilibration time, were adjusted. Each sample $(0.5 \mathrm{~mL})$ was placed in 
a septum-sealed glass vial. The fiber was exposed to the headspace of the sample for 20 min at $40{ }^{\circ} \mathrm{C}$. During this time, samples were stirred with a magnetic stirrer. After equilibration, the fiber was removed from the sample and immediately inserted into the GC injection port for the thermal desorption $(2 \mathrm{~min})$ at $270{ }^{\circ} \mathrm{C}$.

\subsubsection{Gas Chromatography-Mass Spectrometry (GC-MS)}

The extracts were analyzed using a GC-MS Perkin Elmer Clarus 500 instrument (Perkin Elmer, Waltham, MA, USA) equipped with a flame ionization detector (FID). Chromatographic separations were performed on a Varian FactorFour VF-1 fused-silica capillary column (length $60 \mathrm{~m} \times 0.32 \mathrm{~mm}$ ID $\times 1.0 \mu \mathrm{m}$ film thickness). The oven temperature program was as follows: $60^{\circ} \mathrm{C}$ for two min, then, a gradient of $6{ }^{\circ} \mathrm{C} / \mathrm{min}$ to $250{ }^{\circ} \mathrm{C}$ for $10 \mathrm{~min}$, and an injector temperature of $270{ }^{\circ} \mathrm{C}$. Helium was used as the carrier gas with a flow rate of $1.0 \mathrm{~mL} / \mathrm{min}$. Split injection with a split ratio of 1:20 was used. The electron-impact ionization mass spectrometer was operated as follows: ionization voltage, $70 \mathrm{eV}$; ion source temperature, $200^{\circ} \mathrm{C}$; scan mode, 30.0 to 500.0 mass range. The volatile compounds were identified by comparing mass spectra with those in the NIST02 and Wiley libraries. Furthermore, linear retention indices (LRIs) of each compound were calculated using a mixture of n-alkane hydrocarbons (C8-C30, Ultrasci, Ultra Scientific Italia, Bologna, Italy) injected directly into GC injector using the same temperature program reported above. Semiquantitative analysis was performed by normalizing the peak area generated in the FID (\%) without using correction factors (relative response factors, RRFs). All analyses were repeated twice.

\subsection{Human Tissue}

Human synovial membranes were isolated from 6 OA patients and 5 non-OA (fractured) patients that underwent surgical treatment. Full ethical consent was obtained from all donors and the Research Ethics Committee, Sapienza University of Roma (\#290/07, 29 March 2007), and ASL Lazio 2 (\#005605/2019, 3 March 2019) approved the study. The tissues were fixed in 4\% paraformaldehyde in $0.1 \mathrm{M}$ phosphate buffer $\mathrm{pH} 7.2$ immediately after removal from patients.

\subsection{Immunohistochemistry}

Histological sections were deparaffinized and rehydrated in graded ethanol. Endogenous peroxidase activity was blocked by $3 \%$ hydrogen peroxide for $10 \mathrm{~min}$. Antigen retrieval was performed in $10 \mathrm{mM}$ sodium citrate buffer ( $\mathrm{pH}$ 6.0) for $15 \mathrm{~min}$. The sections were then incubated with anti-CB1, anti-CB2, anti-PI PLC $\beta 2$, and anti-PI PLC $\beta 3$ (Santa Cruz Biotechnology, Inc., Dallas, TE, USA), all diluted 1:50, overnight at $4{ }^{\circ} \mathrm{C}$. After incubation, specimens were washed and incubated with the secondary-biotinylated antibody and subsequently, with streptavidin-biotin-peroxidase (DAKOLSAB Kit peroxidase; DAKO, Carpinteria, CA, USA). The signals were developed by incubating with freshly prepared 3,3'-diaminobenzidine (DAB) substrate-chromogen buffer at room temperature. Slides were counterstained with hematoxylin and mounted with permanent mounting media. Negative controls were used in each experiment. The samples were scored semiquantitatively using a score based on the intensity and distribution: 0 , undetectable; $1+$, weak staining; $2+$, medium staining; $3+$, strong staining [28].

\subsection{Human Primary Cell Isolation}

Human primary synoviocytes (FLSs) were isolated from synovial membranes, obtained, as above described, from patients who underwent a total knee and hip arthroplasty. In brief, the synovial membrane fragments were minced and treated with $1 \mathrm{mg} / \mathrm{mL}$ collagenase type IV and $0.25 \%$ trypsin for $1 \mathrm{~h}$, at $37^{\circ} \mathrm{C}$ in agitation. Then, FLSs were grown to 80\% confluence in DMEM (HyClone, Logan, UT, USA) supplemented with L-glutamine, penicillin/streptomycin (Sigma-Aldrich, St. Louis, MO, USA), and $10 \%$ fetal bovine serum (FBS) and cultured at $37^{\circ} \mathrm{C}$ and $5 \% \mathrm{CO}_{2}$. All experiments were carried out with synoviocytes at first passage (p1), isolated from at least 3 different donors. 


\subsection{Immunofluorescence}

Vimentin, CB2, and PI-PLC $\beta 2$ were visualized by immunofluorescence. Cells were plated at a density of $8 \times 10^{3} / \mathrm{cm}^{2}$ and cultured for $48 \mathrm{~h}$ and then, washed in PBS, fixed in $4 \%$ paraformaldehyde in PBS for $15 \mathrm{~min}$ at $4{ }^{\circ} \mathrm{C}$, and permeabilized with $0.5 \%$ Triton-X 100 in PBS for $10 \mathrm{~min}$ at room temperature. After blocking with 3\% bovine serum albumin (BSA) in PBS for $30 \mathrm{~min}$ at room temperature, cells were incubated at $1 \mathrm{~h}$, at room temperature, with mouse monoclonal anti-vimentin antibody (Proteintech Group, Manchester, UK) 1:50, mouse monoclonal anti-CB2 antibody 1:150, and mouse monoclonal anti-PI-PLC $\beta 2$ antibody (Santa Cruz Biotechnology) 1:50. Cells were washed with PBS and then, incubated for $1 \mathrm{~h}$, at room temperature, with Alexa Fluor 488 donkey anti-rabbit antibody 1:300 (Invitrogen, Thermo Fisher Scientific, Waltham, MA, USA), to stain vimentin green; with Alexa Fluor 488 donkey anti-goat antibody 1:600 (Invitrogen, Thermo Fisher Scientific), to stain CB2 receptors green; and Alexa Fluor 595 donkey anti-rabbit antibody 1:300 (Invitrogen, Thermo Fisher Scientific), to stain PI-PLC $\beta 2$ red. Slides were washed and then, stained with DAPI (Invitrogen, Thermo Fisher Scientific) to visualize the nuclei. The images were captured by a Leica DM IL LED optical microscope, using an AF6000 modular microscope (Leica Microsystem, Milan, Italy).

\subsection{Densitometric Analysis}

The free software ImageJ (https://imagej.nih.gov/ij/) was used to perform the densitometric analysis of protein production. For each cell culture condition, the integrated density values of fluorescence were considered.

\subsection{Cell Treatment}

Cells were left untreated (CTL) or treated, for the required time, with $0.1 \mathrm{mg} / \mathrm{mL}$ of Harpagophytum procumbens root extract (HPE) dissolved in deionized water $\left(\mathrm{HPE}_{\mathrm{H} 2 \mathrm{O}}\right)$, DMSO $\left(\mathrm{HPE}_{\mathrm{DMSO}}\right), 100 \% v / v$ $\mathrm{EtOH}\left(\mathrm{HPE}_{\mathrm{EtOH} 100}\right)$, and 50\% v/v EtOH ( $\left.\mathrm{HPE}_{\mathrm{EtOH} 50}\right)$. Experiments were independently repeated at least three times.

\subsection{Cell Viability}

To assess a potential cytotoxic effect of $H$. procumbens extracts on FLSs at different concentrations and time points, an MTS (3-(4,5-dimethylthiazol-2-yl)-5-(3-carboxymethoxyphenyl)2-(4-sulfophenyl)-2 $\mathrm{H}$-tetrazolium)-based colorimetric assay was performed (Promega Corporation, Madison, WI, USA). Briefly, $8 \times 10^{3}$ cells per well were seeded in a 96-well plate. The day after seeding, cells were starved overnight in reduced serum medium, in order to align cell cycle progression. Cells were then left untreated (CTL) or treated with $H$. procumbens extracts for 24,48 , and $72 \mathrm{~h}$. After each time point, $100 \mu \mathrm{L}$ MTS solution was added to the wells. Spectrophotometric absorbance was directly measured at $492 \mathrm{~nm}$ after $3 \mathrm{~h}$ incubation.

\subsection{RNA Extraction and Reverse Transcription}

Total RNA was extracted with TRIZOL (Invitrogen, Thermo Fisher Scientific), purified using a micro RNeasy column (Qiagen, Valencia, CA, USA), and reverse transcribed by Improm II enzyme, (Promega Corporation, Madison, WI, USA), according to the manufacturers' instructions.

\subsection{Quantitative Real-Time PCR}

Quantitative real-time PCR analysis was performed using an ABI Prism 7300 (Applied Biosystems, Thermo Fisher Scientific). Amplification was carried out using SensimixPlus SYBR master mix (Bioline, London, UK). Primers were designed using Primer Express software (Applied Biosystems) and were synthesized by Biofab Research (Rome, Italy). Primers' sequences are reported in Table 1. 
Table 1. Sequences of the primers used in RT-PCR analysis.

\begin{tabular}{cc}
\hline Gene & Primer Sequences \\
\hline CB1 & Forward: 5'-TTCCTTCTTGTGAAGGCACTG-3' \\
NM_016083 & Reverse: 5'-TCTTGACCGTGCTCTTGATGC-3' \\
\hline CB2 & Forward: 5'-ATGCTGTGCCTCATCAACTC-3' \\
NM_001841 & Reverse: 5'-CTCACACACTTCTTCCAGTG-3' \\
\hline FAAH & Forward: 5'-CAGCTTTCCTCAGCAACATG-3' \\
NM_001441 & Reverse: 5'-CAATCACGGTTTTGCGGTAC-3' \\
\hline 18S & Forward: 5'-CGCCGCTAGAGGTGAAATTC-3' \\
NM_003286 & Reverse: 5'-CATTCTTGGCAAATGCTTTCG-3' \\
\hline
\end{tabular}

Data were analyzed by the $2^{-\Delta \Delta C t}$ method, which determines the transcript abundance relative to the $18 \mathrm{~S}$ housekeeping gene [29].

\subsection{FAAH Inhibition}

The potential ability of the tested extract to inhibit fatty acid amide hydrolase (FAAH) was evaluated using a commercial fluorescence-based kit (Cayman's FAAH Inhibitor Screening Assay Kit, Vinci Biochem, Vinci (FI), Italy), according to the manufacturer's instructions. The fluorescence of the FAAH-catalyzed product was measured at an excitation wavelength of 340 to $360 \mathrm{~nm}$ and an emission wavelength of 450 to $465 \mathrm{~nm}$ by a BD Accuri ${ }^{\mathrm{TM}} \mathrm{C} 6$ flow cytometer (BD Biosciences, Milan, Italy). Suitable control wells treated with vehicles (maximum FAAH activity) and with the known FAAH inhibitor JZL 195 (maximum FAAH inhibition) were included. Each treatment was assayed at least in triplicate and at least in two different experiments. The enzyme activity was evaluated as \% inhibition with respect to the vehicle.

\subsection{Statistical Analysis}

All data were obtained from at least three independent experiments, each performed either in duplicate or in triplicate $(n=6$ or $n=9)$. Data were statistically analyzed with two-way repeated measures analysis of variance (ANOVA) with Bonferroni's multiple comparison test using Prism 5.0 software (GraphPad Software, San Diego, CA, USA). The $p$ value $<0.05$ was considered significant.

The Hill equation $\mathrm{E}=\mathrm{E}_{\max } /\left(1+\left(10^{\mathrm{Log} E C 50 / A}\right)\right.$ HillSlope $)\left(\mathrm{E}\right.$, effect at a given concentration; $\mathrm{E}_{\max }$, maximum activity; $\mathrm{EC}_{50}$ or $\mathrm{IC}_{50}$, concentration giving a $50 \%$ inhibition; $\mathrm{A}$, concentration of agonist; Hillslope, slope of the agonist curve) was applied to obtain a concentration-response curve.

\section{Results}

\subsection{Phytochemical Characterization}

The highest levels of total polyphenols were extracted by DMSO and 50\% v/v EtOH, followed by deionized water and pure ethanol. Indeed, their levels in $\mathrm{HPE}_{\mathrm{DMSO}}$ and $\mathrm{HPE}_{\mathrm{EtOH} 50}$ were 1.2- to 1.4-fold higher than in $\mathrm{HPE}_{\mathrm{H} 2 \mathrm{O}}$ and $\mathrm{HPE}_{\mathrm{EtOH} 100}$ (Table 2). Tannins were mainly recovered by $\mathrm{H}_{2} \mathrm{O}$ and DMSO, their amount in $\mathrm{HPE}_{\mathrm{H} 2 \mathrm{O}}$ and $\mathrm{HPE}_{\mathrm{DMSO}}$ being 1.5- to 1.9-fold higher than that found in $\mathrm{HPE}_{\mathrm{EtOH} 100}$ and $\mathrm{HPE}_{\mathrm{EtOH} 50}$ (Table 2). Regarding flavonoids and flavonols, the highest extraction power was exhibited by DMSO; $\mathrm{HPE}_{\mathrm{DMSO}}$ exhibited about 1.5- to 3-fold and 1.5- to 1.7-fold higher concentrations of total flavonoids and flavonols than $\mathrm{HPE}_{\mathrm{EtOH} 50}$ or $\mathrm{HPE}_{\mathrm{EtOH} 100}$ and $\mathrm{HPE}_{\mathrm{H} 2 \mathrm{O}}$, respectively (Table 2). 
Table 2. Amounts of total polyphenols, tannins, flavonoids, and flavonols in the extract from Harpagophytum procumbens root (HPE) dissolved in DMSO (HPE $\mathrm{DMSO}_{\text {) }}, 100 \%$ v/v EtOH (HPE $\mathrm{EtOH}_{100}$ ), $50 \%$ v/v EtOH $\left(\mathrm{HPE}_{\mathrm{EtOH} 50}\right)$, and deionized water $\left(\mathrm{HPE}_{\mathrm{H} 2 \mathrm{O}}\right)$. Data are the mean $\pm \mathrm{SE}$ of at least three independent experiments with three replicates for each experiment $(n=9)$.

\begin{tabular}{|c|c|c|c|c|}
\hline \multirow{2}{*}{ Compounds } & HPE $_{\text {DMSO }}$ & HPE $_{\text {EtOH100 }}$ & HPE $_{\text {EtOH50 }}$ & $\mathrm{HPE}_{\mathrm{H} 2 \mathrm{O}}$ \\
\hline & \multicolumn{4}{|c|}{$\mu \mathrm{g} / \mathrm{mg}$ of Dry Extract (Mean $\pm \mathrm{SE}$ ) } \\
\hline Polyphenols (TAE) & $99.6 \pm 0.05^{* * * \S}$ & $69.6 \pm 0.05$ & $97.9 \pm 0.01 * * \approx \S$ & $84.2 \pm 0.04 * *$ \\
\hline Tannins (TAE) & $14.2 \pm 0.02 * *$ & $9.2 \pm 0.04$ & $9.2 \pm 0.02$ & $17.9 \pm 0.03^{* * *}$ \\
\hline Flavonoids (QE) & $113.0 \pm 5.1^{* * * \S \S}$ & $71.3 \pm 6.6 \S \S$ & $75.1 \pm 6.1 \S \S$ & $37.6 \pm 4.3$ \\
\hline Flavonols (QE) & $43.8 \pm 2.4^{* * * \S \S}$ & $27.6 \pm 3.2$ & $30.1 \pm 2.0 \S$ & $25.1 \pm 2.0$ \\
\hline
\end{tabular}

TAE-tannic acid equivalent. QE-quercetin equivalent. ${ }^{* *} p<0.01$ and ${ }^{* * *} p<0.01$ significantly higher than $\mathrm{HPE}_{\mathrm{EtOH} 100}$ (ANOVA followed by Bonferroni's multiple comparison post hoc test). $\S_{p}<0.05$ and $\$ \S p<0.01$ significantly higher than $\mathrm{HPE}_{\mathrm{H} 2 \mathrm{O}}$ (ANOVA followed by Bonferroni's multiple comparison post hoc test).

Altogether, these results revealed that DMSO is the most suitable for recovering total polyphenols, including tannins, flavonoids, and flavonols, followed by 50\% v/v EtOH, especially for total flavonoids and flavonols. Pure ethanol extract possesses similar features compared to 50\% v/v EtOH regarding total flavonoids and flavonols, with a lower recovery of total polyphenols. Finally, pure deionized water was able to better extract tannins, with significantly lower flavonoid levels.

The SPME-GC-MS analysis highlighted the presence of different volatile compounds in all the samples except for the aqueous $\mathrm{HPE}_{\mathrm{H} 2 \mathrm{O}}$ extract. Among them, eight compounds, listed in Table 3, were identified and their relative percentage amounts were calculated. Eugenol and $\beta$-caryophyllene were the main volatile phytochemicals in all extracts. Eugenol achieved a maximum $51.6 \%$ amount in $\mathrm{HPE}_{\mathrm{ETOH} 50}$, while HPE $\mathrm{DMSO}_{\mathrm{DM}}$ and HPE $\mathrm{ETOH} 100$ contained the highest percentages of $\beta$-caryophyllene (i.e., $77.4 \%$ and $77.1 \%$, respectively). Moreover, $\beta$-pinene $(5.1 \%)$ and isoeugenol $(1.0 \%)$ were found in $\mathrm{HPE}_{\mathrm{ETOH} 50}$, while thymol $(0.8 \%)$ was found in HPE $\mathrm{DMSO}_{\mathrm{DSO}} \alpha$-copaene was also identified in ethanolic extracts $\mathrm{HPE} \mathrm{EtOH}_{100}$ and $\mathrm{HPE}_{\mathrm{EtOH} 50}(6.3 \%$ and $3.7 \%$, respectively). On the other hand, $\alpha$-humulene $(10.0 \% ; 0.8 \%)$ and $\delta$-cadinene $(5.8 \% ; 1.3 \%)$ were detected in $\mathrm{HPE}_{\mathrm{DMSO}}$ and $\mathrm{HPE}_{\mathrm{EtOH} 100}$, respectively.

Table 3. Volatile compounds (relative percentage in the volatile fraction) detected in Harpagophytum procumbens root extract (HPE) dissolved in DMSO (HPE $\mathrm{DMSO}_{\text {) }}$, 100\% v/v EtOH (HPE $\left.\mathrm{EtOH} 100\right), 50 \% v / v$ $\mathrm{EtOH}\left(\mathrm{HPE}_{\mathrm{EtOH} 50}\right)$, and deionized water $\left(\mathrm{HPE}_{\mathrm{H} 2 \mathrm{O}}\right)$.

\begin{tabular}{|c|c|c|c|c|c|c|c|c|}
\hline No. ${ }^{1}$ & Compound $^{2}$ & LRI $^{3}$ & LRI $^{4}$ & MS $^{5}$ & $\begin{array}{c}\text { HPE }_{\text {DMSO }} \\
(\%)\end{array}$ & $\begin{array}{c}\text { HPEEtOH100 }_{\text {Eto }} \\
(\%)\end{array}$ & $\begin{array}{c}\text { HPEEtOH50 }_{\text {Eto }} \\
(\%)\end{array}$ & $\begin{array}{c}\mathrm{HPE}_{\mathrm{H} 2 \mathrm{O}} \\
(\%)\end{array}$ \\
\hline 1 & $\beta$-pinene & 978 & 974 & + & - & - & 5.1 & - \\
\hline 2 & thymol & 1308 & 1310 & + & 0.8 & - & - & - \\
\hline 3 & eugenol & 1339 & 1344 & + & 6.0 & 14.6 & 51.6 & - \\
\hline 4 & $\alpha$-copaene & 1381 & 1387 & + & - & 6.3 & 3.7 & - \\
\hline 5 & $\beta$-caryophyllene & 1412 & 1416 & + & 77.4 & 77.1 & 38.6 & - \\
\hline 6 & isoeugenol & 1432 & 1439 & + & - & - & 1.0 & - \\
\hline 7 & $\alpha$-humulene & 1450 & 1454 & + & 10.0 & 0.8 & - & - \\
\hline 8 & $\begin{array}{c}\delta \text {-cadinene } \\
\text { Total }(\%)\end{array}$ & 1528 & $1530^{+}$ & + & $\begin{array}{c}5.8 \\
100.0\end{array}$ & $\begin{array}{c}1.3 \\
100.0\end{array}$ & $\begin{array}{c}- \\
100.0\end{array}$ & - \\
\hline
\end{tabular}

\footnotetext{
${ }^{1}$ Compound identification number; ${ }^{2}$ compounds are reported according their elution order on column; ${ }^{3}$ linear retention indices measured on apolar columns; ${ }^{4}$ linear retention indices from literature; ${ }^{+}$normal alkane RI; 5 identification by MS spectra, $\operatorname{tr}<0.1 \%$.
}

\subsection{Expression of Cannabinoid Receptors in OA Synovial Membrane}

The presence of CB1 and CB2 receptors and PI-PLC $\beta 2$ and $\beta 3$ was detected by immunohistochemistry in synovial membranes isolated both from non-OA and OA patients. CB1 receptors were expressed in both normal and pathological tissues but with different scores; they were moderately present in non-OA patients (score 1+), while strongly present in OA patients (score 3+) (Figure 1, left-upper panel). CB2 receptors were detected only in non-OA tissue (score 2+) (Figure 1, 
left-bottom panel). Regarding the presence of PI-PLC $\beta 2$ and $\beta 3$, we found that the expression of PI-PLC $\beta 2$ showed a lesser staining in non-OA (score $2+$ ) than OA tissue (score 3+), and it was localized in the cytoplasm of both tissues (Figure 1, right-upper panel). PI-PLC $\beta 3$ was equally expressed in tissues from non-OA (score 3+) and OA patients (score 3+) (Figure 1, right-bottom panel). We also analyzed PI-PLC $\beta 1$ and PI-PLC $\beta 4$, finding that were both barely expressed both in non-OA and OA synovial membranes.
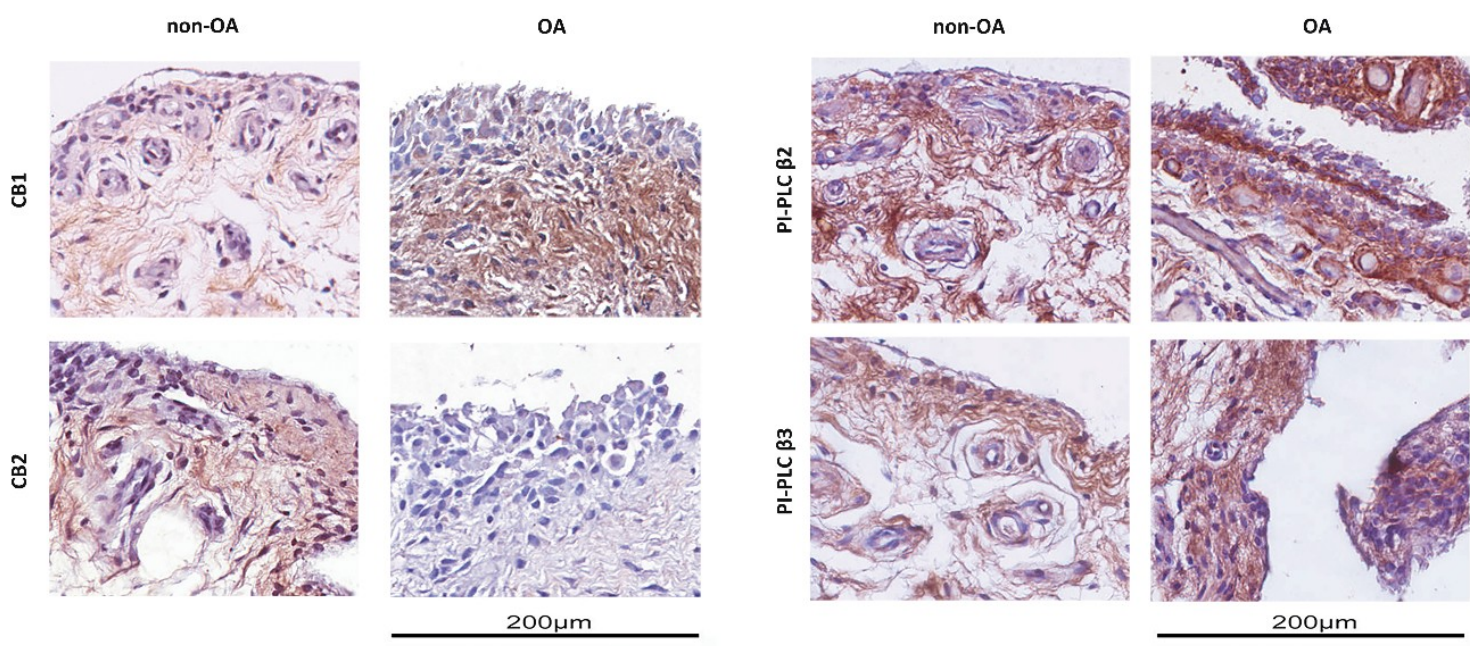

Figure 1. Immunohistochemical analysis of synovial membranes from OA (osteoarthritis) and non-OA patients. Left panel: Slices were stained with anti-CB1 and anti-CB2 receptor antibodies. Right panel: Slices were stained with anti-PI-PLC $\beta 2$ and anti-PI-PLC $\beta 3$ antibodies. Slides were counterstained with hematoxylin and mounted with permanent mounting media. This figure shows representative images of different experiments $(n=5$ non-OA and $n=6$ OA).

\subsection{Effects of Harpagophytum Extracts on Synoviocyte Cell Viability}

Synoviocytes were isolated by both OA and non-OA tissues. Two types of synoviocytes are present in the synovial membrane, A and B. The synoviocytes A are macrophage-like and the synoviocytes B are fibroblast-like synoviocytes (FLSs). The latter are characterized by their elongated shape and the expression of vimentin [30]; we verified the expression of this protein in our cells, finding that they were able to produce vimentin (Figure $2 \mathrm{~A}$ ).

The effects of Harpagophytum procumbens extracts on FLS cell viability were determined by the MTS colorimetric method. The extracts, tested at $1 \mathrm{mg} / \mathrm{mL}, 0.5 \mathrm{mg} / \mathrm{mL}$, and $0.1 \mathrm{mg} / \mathrm{mL}$ for 24,48 , and $72 \mathrm{~h}$, did not show detrimental effects at any analyzed concentration or time point (Figure 2B). We decided to use the $0.1 \mathrm{mg} / \mathrm{mL}$ concentration for further experiments.

\subsection{Mechanism of Action of Harpagophytum Extracts on FLSs}

In order to assay the effects of the different extracts on cannabinoid receptor expression, they were added to cell culture medium at a concentration of $0.1 \mathrm{mg} / \mathrm{mL}$ for $24 \mathrm{~h}$, then, the mRNA expression level of $\mathrm{CB} 1$ and $\mathrm{CB} 2$ receptors was analyzed. The $\mathrm{HPE}_{\mathrm{H} 2 \mathrm{O}}$ and $\mathrm{HPE} \mathrm{DMSO}_{\mathrm{D}}$ and to a lesser extent, $\mathrm{HPE}_{\mathrm{EtOH} 50}$, were able to increase the CB2 mRNA expression level, whereas HPE $\mathrm{EtOH}_{00}$ did not show any effect (Figure 3). CB1 receptor mRNA expression level was increased by $\mathrm{HPE}_{\mathrm{H} 2 \mathrm{O}}$ and $\mathrm{HPE} \mathrm{DMSO}_{\mathrm{D}}$

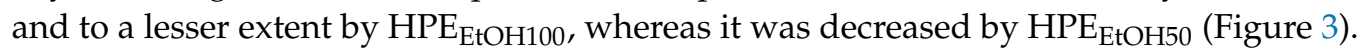


A

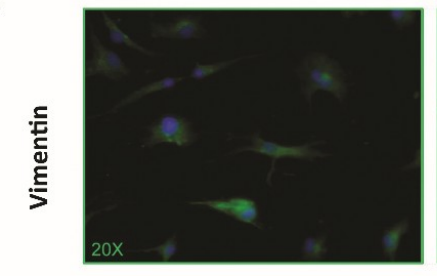

B

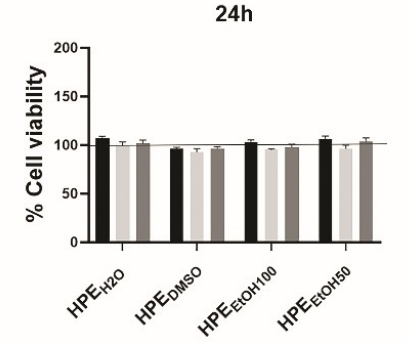

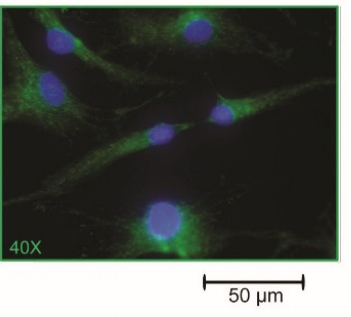

$48 \mathrm{~h}$

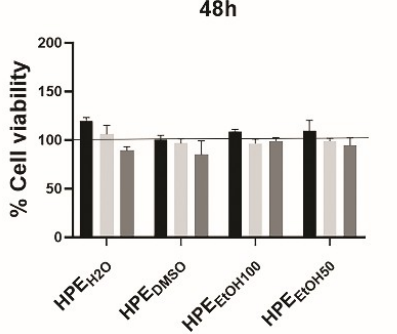

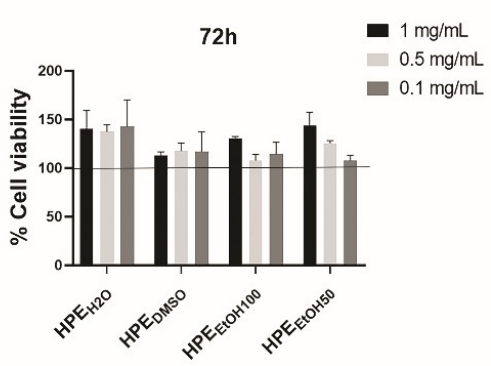

Figure 2. Characterization of human primary synoviocytes (FLSs) and analysis of cell viability. (A) Human primary FLSs, isolated by synovial membranes and cultured in vitro, were stained with anti-vimentin primary antibody and with Alexa Fluor 488 (green) secondary antibody. (B) Cell viability was assessed by the MTS colorimetric method, and FLSs were treated with three concentrations, 1, 0.5, and $0.1 \mathrm{mg} / \mathrm{mL}$ of Harpagophytum procumbens root extract (HPE) dissolved in deionized water $\left(\mathrm{HPE}_{\mathrm{H} 2 \mathrm{O}}\right)$, DMSO (HPE $\mathrm{DMSO}_{\text {) }}, 100 \%$ v/v EtOH ( $\left.\mathrm{HPE}_{\mathrm{EtOH} 100}\right)$, and 50\% v/v EtOH (HPE $\left.\mathrm{EtOH}_{50}\right)$, for 24, 48, and $72 \mathrm{~h}$. Cell viability of treated samples was normalized to the untreated cells, which is reported as $100 \%$ and represented by a horizontal line.

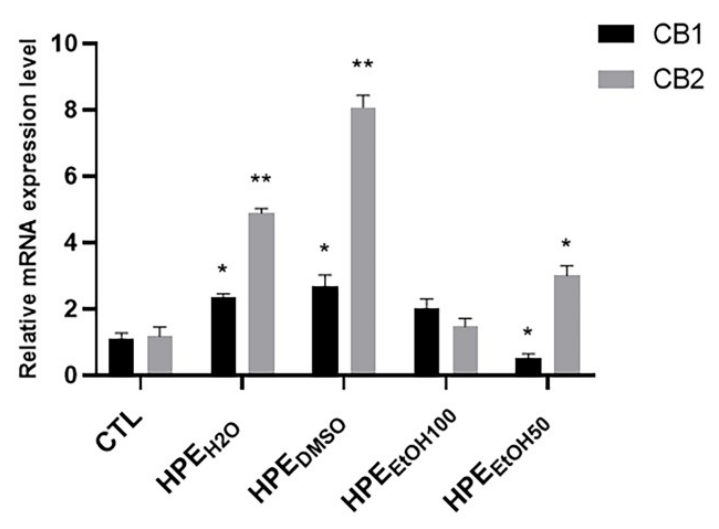

Figure 3. Effects of all HPE extracts on CB1 and CB2 mRNA expression level in human primary FLSs. After $24 \mathrm{~h}$ treatment with $0.1 \mathrm{mg} / \mathrm{mL}$ of Harpagophytum procumbens root extract (HPE) dissolved in deionized water $\left(\mathrm{HPE}_{\mathrm{H} 2 \mathrm{O}}\right)$, DMSO (HPE $\left.\mathrm{DMSO}\right), 100 \%$ v/v EtOH ( $\left.\mathrm{HPE} \mathrm{EtOH}_{100}\right)$, and 50\% v/v EtOH $\left(\mathrm{HPE}_{\mathrm{EtOH} 50}\right)$, cells were harvested and mRNA was extracted and analyzed by RT-PCR. CB1 and CB2 receptor mRNA levels were reported as relative mRNA expression level with respect to 18S mRNA $\left(2^{-\Delta \Delta C t}\right.$ method). Results are expressed as mean \pm S.E.M. of data obtained by three different experiments. Statistical significance was ${ }^{*} p<0.05 ;{ }^{* *} p<0.01$.

Considering that only CB2 receptors are associated with inflammation and pain in peripheral tissues, we verified whether the $\mathrm{CB} 2$ receptors also increased at the protein level by immunofluorescence staining. FLSs were treated with $0.1 \mathrm{mg} / \mathrm{mL}$ extracts for 24 and $48 \mathrm{~h}$, then, the cells were stained with antibody anti-CB2. We found that $\mathrm{HPE}_{\mathrm{H} 2 \mathrm{O}}$ and $\mathrm{HPE} \mathrm{DMSO}_{\mathrm{D}}$ extracts were able to stimulate the exposure in membrane of CB2 receptors, both at 24 and $48 \mathrm{~h}$, whereas $\mathrm{HPE} \mathrm{EtOH}_{50}$ and $\mathrm{HPE} \mathrm{EtOH}_{100}$ did not stimulate CB2 receptor expression at any analyzed time (Figure 4 and Figure S1). Taking into account that the expression of PI-PLC $\beta 2$ was increased in synovial membranes from OA patients, we verified whether the $\mathrm{HPE}$ extracts were able to reduce the production of this phospholipase. $\mathrm{HPE}$ 
and $\mathrm{HPE}_{\mathrm{DMSO}}$ were able to inhibit the expression of PI-PLC $\beta 2$, whereas $\mathrm{HPE} \mathrm{EtOH}_{\mathrm{E} 0}$ and $\mathrm{HPE} \mathrm{EtOH}_{\mathrm{E} 100}$ did not show effects (Figure 4).
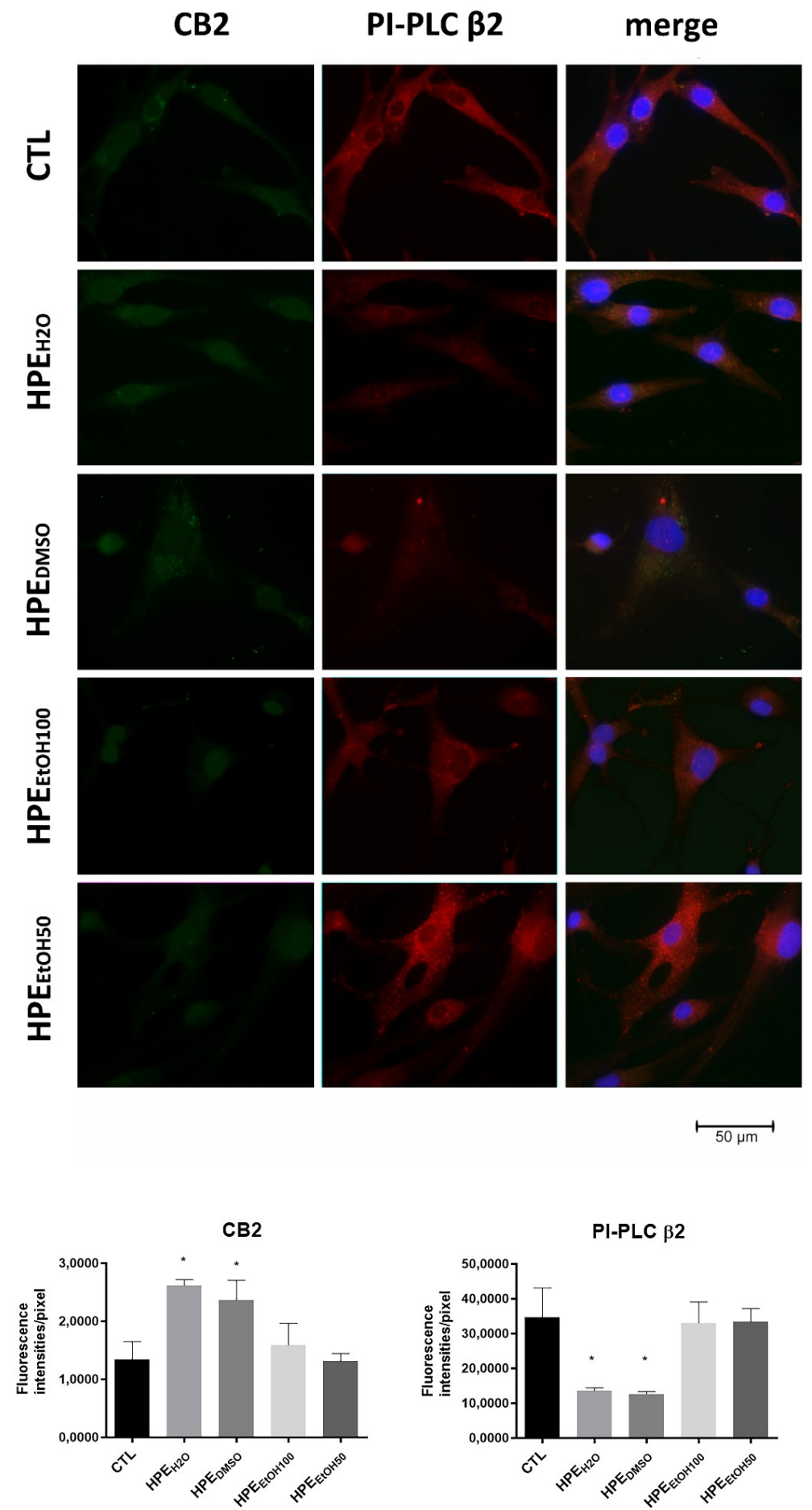

Figure 4. Effects of all HPE extracts on CB2 receptor and PI-PLC $\beta 2$ protein production. Upper panel: Cells were treated with $0.1 \mathrm{mg} / \mathrm{mL}$ of Harpagophytum procumbens root extract (HPE) dissolved in deionized water $\left(\mathrm{HPE}_{\mathrm{H} 2 \mathrm{O}}\right)$, DMSO ( $\left.\mathrm{HPE}_{\mathrm{DMSO}}\right), 100 \% v / v \mathrm{EtOH}\left(\mathrm{HPE}_{\mathrm{EtOH} 100}\right)$, and 50\% v/v EtOH $\left(\mathrm{HPE}_{\mathrm{EtOH}}\right)$, for $24 \mathrm{~h}$ and then, analyzed by immunofluorescence using anti-CB2 and anti-PI-PLC $\beta 2$ primary antibodies and Alexa Fluor 488 (green, CB2) and Alexa Fluor 568 (red, PI-PLC $\beta 2$ ) secondary antibodies, respectively. Nuclei were stained with DAPI (original magnification $40 \times$ ). Lower panel: The pixel intensities in the region of interest were obtained by ImageJ. ${ }^{*} p<0.05$. 


\subsection{Inhibition of Fatty Acid Anandamide Hydrolase}

In order to check whether the HPE extracts were able to affect the fatty acid amide hydrolase (FAAH), we analyzed both the FAAH mRNA expression level and enzymatic activity. $\mathrm{HPE}_{\mathrm{H} 2 \mathrm{O}}$ was able to decrease the FAAH mRNA level even if the downregulation was not statistically significant, whereas all other extracts were ineffective (Figure 5A). Interestingly, under our experimental conditions, all the extracts were able to interfere with the FAAH activity, although with different efficacy and potency (Figure 5B). Particularly, $\mathrm{HPE}_{\mathrm{H} 2 \mathrm{O}}$ was the least effective sample, achieving a maximum $58.5 \%$ enzyme inhibition at the highest concentration of $2500 \mu \mathrm{g} / \mathrm{mL}$. Conversely, the other extracts could completely inhibit the FAAH enzyme, HPE $\mathrm{EtOH}_{\mathrm{E} 100}$ being slightly more potent than HPE $\mathrm{DMSO}_{\mathrm{D}}$ and HPE $\mathrm{EtOH}_{50}$, which displayed similar potencies. Indeed, the $\mathrm{IC}_{50}$ value of $\mathrm{HPE} \mathrm{EtOH}_{\mathrm{E} 100}$ was about 1.2- to 1.5-fold lower than those of $\mathrm{HPE}_{\mathrm{EtOH} 50}$ and $\mathrm{HPE}_{\mathrm{DMSO}}$ (Table 4). Under the same experimental conditions, $100 \mu \mathrm{g} / \mathrm{mL}$ harpagoside (corresponding to $200 \mu \mathrm{M}$ ) was found to be ineffective in the inhibition of the FAAH enzyme (about 9\% inhibition compared the control). Conversely, the positive control JZL $195(20 \mu \mathrm{M}$ corresponding to $8.7 \mu \mathrm{g} / \mathrm{mL})$ produced a maximum $90 \%$ enzyme inhibition (Table 4$)$. As expected, the positive control was significantly more potent than the HPE extracts (Table 4).

A

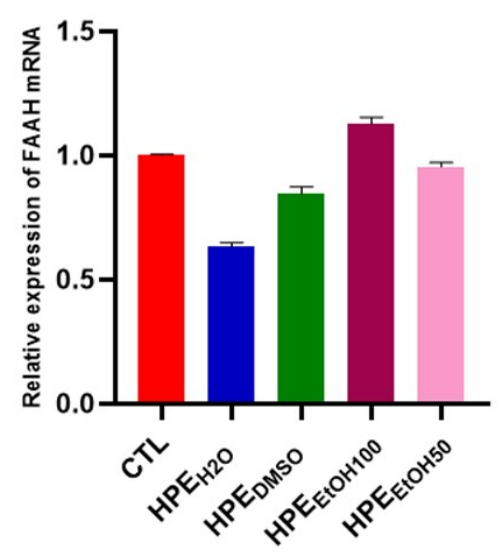

B

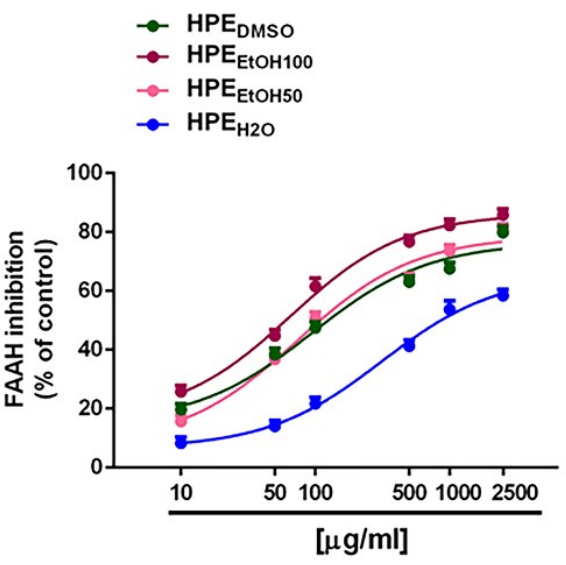

Figure 5. Effects of Harpagophytum procumbens root extract (HPE) on fatty acid anandamide hydrolase (FAAH) expression and enzymatic activity. (A) Cells were treated with $0.1 \mathrm{mg} / \mathrm{mL}$ of Harpagophytum procumbens root extract (HPE) dissolved in deionized water ( $\mathrm{HPE}_{\mathrm{H} 2 \mathrm{O}}$ ), DMSO (HPE $\left.\mathrm{DMSO}\right), 100 \%$ $v / v \mathrm{EtOH}\left(\mathrm{HPE}_{\mathrm{EtOH} 100}\right)$, and 50\% v/v EtOH $\left(\mathrm{HPE}_{\mathrm{EtOH} 50}\right)$, for $24 \mathrm{~h}$. Cells were then harvested, and mRNA was extracted and analyzed by RT-PCR. FAAH mRNA levels were reported as relative mRNA expression level with respect to $18 \mathrm{~S}$ mRNA $\left(2^{-\Delta \Delta C t}\right.$ method). Results are expressed as mean \pm S.E.M. of data obtained by three different experiments. (B) Concentration-response curves showing the inhibitory effects on FAAH from $\mathrm{HPE}_{\mathrm{DMSO}}, 100 \% v / v \mathrm{HPE}_{\mathrm{EtOH} 100}, 50 \% v / v \mathrm{HPE}_{\mathrm{EtOH} 50}$, and $\mathrm{HPE}_{\mathrm{H} 2 \mathrm{O}}$. Data are the mean $\pm S E$ of at least three independent experiments with two replicates for each experiment $(n=6)$.

Table 4. $\mathrm{IC}_{50}$ values of Harpagophytum procumbens root extract (HPE) dissolved in DMSO (HPE $\mathrm{DMSO}_{\text {), }}$ $100 \% v / v \mathrm{EtOH}\left(\mathrm{HPE}_{\mathrm{EtOH} 100}\right), 50 \% v / v \mathrm{EtOH}\left(\mathrm{HPE}_{\mathrm{EtOH} 50}\right)$, and deionized water $\left(\mathrm{HPE}_{\mathrm{H} 2 \mathrm{O}}\right)$ and the positive control JZL 195 in the FAAH inhibition assay.

\begin{tabular}{cc}
\hline Harpagophytum procumbens Root Extract & $\mathrm{IC}_{50}(\mathrm{CL}) \mu \mathrm{g} / \mathrm{mL}$ \\
\hline $\mathrm{HPE}_{\mathrm{DMSO}}$ & $94.7(23.8-97.5)$ \\
$\mathrm{HPE}_{\mathrm{E} \mathrm{OH} 100}$ & $65.5(19.2-87.9)^{*}$ \\
$\mathrm{HPE}_{\mathrm{EtOH} 50}$ & $73.8(24.5-94.3)$ \\
$\mathrm{HPE}_{\mathrm{H} 2 \mathrm{O}}$ & - \\
$\mathrm{JZL}_{195}$ & $0.03(0.01-0.06) *$ \\
\hline
\end{tabular}

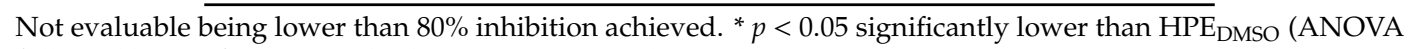
followed by Bonferroni's multiple comparison post hoc test). 


\section{Discussion}

The aim of this study was to investigate the effects of Harpagophytum procumbens extract (HPE) on fibroblast-like synoviocytes (FLSs) from osteoarthritis patients, with particular attention on the endocannabinoid-mediated mechanisms. Osteoarthritis $(\mathrm{OA})$ is characterized by chronic inflammation, and it is currently treated with anti-inflammatory drugs, which are only able to counteract the symptoms [2,31]. Several nutraceuticals, such as glucosamine, chondroitin sulfate, and curcumin, are administered with the aim of delaying the cartilage degradation, with inconsistent results [32]. Extracts from plants are also traditionally used to treat OA [16]. Among them, H. procumbens DC. has been studied for its chondroprotective activities, mainly for the ability to inhibit the production of proinflammatory mediators, such as TNF $\alpha$ and IL-1 $\beta$, and enzymes able to hydrolyze the extracellular matrix components, metalloproteases, and elastase [19].

Iridoid glycosides have received major attention as possible bioactive compounds of $H$. procumbens secondary metabolites [33]. Harpagoside is the most investigated one, and it is considered a reference standard of $H$. procumbens for titration purposes [15]. The anti-inflammatory activity of harpagoside has been found to be mediated by the inhibition of COX-1 and COX-2 enzymes along with by a lowered cytokine and NO release [33]. It was also able to counteract inflammation in primary human osteoarthritic chondrocytes through the suppression of c-FOS/AP-1 signal and the inhibition of proinflammatory cytokine and fibrinogenic factor production [23]. Moreover, harpagoside requires hydrolysis to a bioactive metabolite to exert its anti-inflammatory activity [34].

Despite this promising evidence, the anti-inflammatory properties of harpagoside cannot fully explain those of the entire H. procumbens phytocomplex, thus, suggesting that other compounds can contribute to the activity of the plant $[15,33]$. In the phytocomplex, some phenylpropanoids were reported to contribute to the $H$. procumbens anti-inflammatory effects [15].

Some studies have highlighted that plant roots can release volatile compounds as a defense strategy to counteract pathogen and fungal infections and to mediate the interaction between plant and soil bacteria [35-37]. Accordingly, our SPME-GC-MS analysis of HPE extracts highlighted the presence of several volatile compounds, mainly recovered by $\mathrm{HPE}_{\mathrm{DMSO}}, 100 \% v / v \mathrm{HPE} \mathrm{EtOH}_{\text {, and } 50 \%}$ $v / v \mathrm{HPE}_{\mathrm{EtOH}}$. Among these volatile compounds, $\beta$-caryophyllene and eugenol were identified to be the major sesquiterpene and monoterpene present, followed by the sesquiterpenes $\alpha$-humulene and $\alpha$-copaene. Previously, 31 different volatile compounds, obtained by an heptanoic extraction, were characterized in $H$. procumbens root, although neither sesquiterpenes nor monoterpenes were detected [38]. In several preclinical models, $\beta$-caryophyllene, $\alpha$-humulene, and eugenol have been shown to possess anti-inflammatory activities, affecting proinflammatory cytokine secretion and inhibiting inducible nitric oxide synthase (iNOS) and cyclooxygenase (COX-2) expression $[39,40]$. $\beta$-caryophyllene acts as an agonist of the endocannabinoid CB2 receptor, which is involved in the modulation of inflammation and the immune system and inhibits the fatty acid amide hydrolase enzyme [41,42]. Recent evidence highlighted the ability of this sesquiterpene to reduce articular and systemic inflammation in several animal models of arthritis $[25,43,44]$. Particularly, its antiarthritic effects in human articular chondrocytes were mediated by a crosstalk between CB2 and PPAR- $\gamma$ receptors [25].

In articular joints, FLSs are involved both in supporting health chondrocytes and the immune system during inflammation [45]. In this study, we decided to use FLSs isolated from human synovial membranes as an in vitro model to study the effects of $H$. procumbens extracts. Preliminarily, the expression of CB2 receptors was checked in synovial membranes from OA and non-OA joints, and we found that it was expressed only in non-OA joints and was completely absent in OA. This finding agrees with the observations of Fukuda and coworkers, who found that $\mathrm{CB} 2$ receptors are expressed in rheumatoid arthritis (RA) synovial membranes and not in OA synovial membranes [46]. Moreover, they showed that CB2 plays an anti-inflammatory role in RA, and the treatment of RA synoviocytes with an agonist of CB2 blocked the production of proinflammatory mediators, through the inhibition of adenylyl cyclase, which, in turn, did not produce cAMP. Thus, protein kinase A was not activated, 
finally leading to failure of the activation of NF- $\mathrm{KB}$ [46]. Accordingly, the absence of CB2 in OA synovial membranes, which has been observed in our samples, can be associated with the activated inflammatory pathways present in joints of OA patients. Several studies showed the activation of NF- $\mathrm{kB}$ in OA joints [34,47]; thus, the activation of pathways or molecules that can downregulate NF- $\mathrm{kB}$ activity is very desirable $[48,49]$. Moreover, Sophocleous and coworkers showed that $\mathrm{CB} 2^{--}$mice had a greater susceptibility to OA [4].

The phosphoinositide (PI)-dependent signal plays important roles in many cellular processes, among them proinflammatory pathways, the alteration of which is involved in the onset and progression of several diseases [50]. The PI-phospholipase C (PI-PLC) $\beta 1$ isoform has been described as differently modulated in osteoblasts from OA and RA patients [51]. We analyzed the synovial membranes from $\mathrm{OA}$ and non-OA patients for the presence of PI-PLC $\beta 1-\beta 4$, finding that $\beta 1$ and $\beta 4$ were almost unexpressed both in $\mathrm{OA}$ and non-OA tissues, whereas $\beta 3$ was equally expressed in both tissues. Interestingly, $\beta 2$ was highly expressed in OA and poorly expressed in non-OA, suggesting that only $\beta 2$ is related to injured OA tissue. These findings prompted us to evaluate whether the H. procumbens extracts were able to modulate both CB2 and PI-PLC $\beta 2$ in isolated human primary FLSs, finding that $\mathrm{HPE}_{\mathrm{H} 2 \mathrm{O}}$ and $\mathrm{HPE}_{\mathrm{DMSO}}$ stimulated the expression of $\mathrm{CB} 2$ receptors and decreased the expression of PI-PLC $\beta 2$, whereas the HPE $\mathrm{EtOH} 50_{0}$ had a weak effect and HPE $\mathrm{EtOH} 100_{\text {was }}$ completely ineffective on the expression of these two molecules. Thus, the ability of $\mathrm{HPE}_{\mathrm{H} 2 \mathrm{O}}$ and $\mathrm{HPE}_{\mathrm{DMSO}}$ to increase the expression of $\mathrm{CB} 2$ receptors may explain the anti-inflammatory and antinociceptive activity of this plant. The role of PI-PLC $\beta 2$ in inflammatory pathways has not been described so far; for this reason, the inhibition of its expression needs to be explored more in depth. We suppose that its expression in OA tissue could be associated with stimulation of the proinflammatory pathway through the activation of protein kinase $C$.

Moreover, further anti-inflammatory mechanisms are affected, as shown by the inhibition of FAAH in all the analyzed HPE extracts. The best inhibition was shown by HPE $\mathrm{EtOH}_{100}$ and $\mathrm{HPE}_{\mathrm{EtOH} 50}$, so we can hypothesize that volatile compounds, such as $\beta$-caryophyllene, eugenol, and $\alpha$-humulene, can be involved in these HPE effects.

\section{Conclusions}

Harpagoside, harpagide, and procumbide are present in all extracts, and ethnopharmacology considers them primarily responsible for $H$. procumbens activity. However, several studies, performed at the molecular level, showed that the administration of these purified compounds cannot justify the analgesic activity of the whole phytocomplex. The present study showed that further extractions with deionized water or DMSO can recover some bioactive compounds able to increase the synthesis of CB2 receptors, which are unexpressed in the osteoarthritic tissues. Moreover, the deionized water and DMSO extracts decrease the expression of the PI-PLC $\beta 2$ isoform, which, in turn, could inhibit the FAAH synthesis of endocannabinoids. Interestingly, DMSO, 50\% ethanolic, and to a greater extent, $100 \%$ ethanolic extracts, were able to inhibit FAAH activity.

Further studies in in vitro cell models and in vivo animal models are needed to support the hypothesis that $H$. procumbens root can be effective in controlling osteoarthritic pain, through the modulation of endocannabinoid system. The specific contribution of iridoid glucosides, polyphenols, and terpenes deserve to be further investigated too.

Supplementary Materials: The following materials are available online at http://www.mdpi.com/2072-6643/12/ 9/2545/s1, Figure S1: Effects of all HPE extracts on CB2 receptor and PI-PLC $\beta 2$ protein production after 48 h treatment.

Author Contributions: Conceptualization, A.S.d., A.D.S. and S.A.; methodology and investigation, A.M., A.D.S., M.L., S.G., V.D.M., M.G., P.D.V.; data curation, A.S.d., A.M., A.D.S.; writing-original draft preparation, A.S.d., S.A. and A.D.S. All authors have read and agree to the published version of the manuscript.

Funding: This research was partially funded by "Progetto di Facoltà 2019". 
Acknowledgments: We would like to thank Ssa E. Bisicchia for helpful discussion. A.D.S. fellowship was funded by grants from Sapienza University, "Progetto di Ateneo 2019".

Conflicts of Interest: The authors declare no conflict of interest.

\section{References}

1. Robinson, W.H.; Lepus, C.M.; Wang, Q.; Raghu, H.; Mao, R.; Lindstrom, T.M.; Sokolove, J. Low-grade inflammation as a key mediator of the pathogenesis of osteoarthritis. Nat. Rev. Rheumatol. 2016, 12, 580-592. [CrossRef] [PubMed]

2. Goldring, S.R.; Goldring, M.B. Changes in the osteochondral unit during osteoarthritis: Structure, function and cartilage bone crosstalk. Nat. Rev. Rheumatol. 2016, 12, 632-644. [CrossRef] [PubMed]

3. Turcotte, C.; Blanchet, M.R.; Laviolette, M.; Flamand, N. The CB2 receptor and its role as a regulator of inflammation. Cell. Mol. Life Sci. 2016, 73, 4449-4470. [CrossRef]

4. Sophocleous, A.; Börjesson, A.E.; Salter, D.M.; Ralston, S.H. The type 2 cannabinoid receptor regulates susceptibility to osteoarthritis in mice. Osteoarthr. Cartil. 2015, 23, 1586-1594. [CrossRef] [PubMed]

5. Chiou, L.C.; Hu, S.S.J.; Ho, Y.C. Targeting the cannabinoid system for pain relief? Acta Anaesthesiol. Taiwanica 2013, 51, 161-170. [CrossRef]

6. Zoratti, C.; Kipmen-Korgun, D.; Osibow, K.; Malli, R.; Graier, W.F. Anandamide initiates Ca ${ }^{2+}$ signaling via CB2 receptor linked to phospholipase C in calf pulmonary endothelial cells. Br. J. Pharmacol. 2003, 140, 1351-1362. [CrossRef]

7. Ferrara, A.L.; Piscitelli, F.; Petraroli, A.; Parente, R.; Galdiero, M.R.; Varricchi, G.; Marone, G.; Triggiani, M.; Di Marzo, V.; Loffredo, S. Altered metabolism of phospholipases, diacylglycerols, endocannabinoids, and $\mathrm{N}$-Acylethanolamines in patients with mastocytosis. J. Immunol. Res. 2019. [CrossRef]

8. Nagao, M.; Tanabe, N.; Manaka, S.; Naito, M.; Sekino, J.; Takayama, T.; Kawato, T.; Torigoe, G.; Kato, S.; Tsukune, N.; et al. LIPUS suppressed LPS-induced IL-1 $\alpha$ through the inhibition of NF- $\kappa B$ nuclear translocation via AT1-PLC $\beta$ pathway in MC3T3-E1 cells. J. Cell. Physiol. 2017, 232, 3337-3346. [CrossRef]

9. Dunn, S.L.; Wilkinson, J.M.; Crawford, A.; Bunning, R.A.D.; Le Maitre, C.L. Expression of Cannabinoid Receptors in Human Osteoarthritic Cartilage: Implications for Future Therapies. Cannabis Cannabinoid Res. 2016, 1, 3-15. [CrossRef]

10. Richardson, D.; Pearson, R.G.; Kurian, N.; Latif, M.L.; Garle, M.J.; Barrett, D.A.; Kendall, D.A.; Scammell, B.E.; Reeve, A.J.; Chapman, V. Characterisation of the cannabinoid receptor system in synovial tissue and fluid in patients with osteoarthritis and rheumatoid arthritis. Arthritis Res. Ther. 2008. [CrossRef]

11. McAlindon, T.E.; Bannuru, R.R. Latest advances in the management of knee OA. Nat. Rev. Rheumatol. 2018, 14, 73-74. [CrossRef] [PubMed]

12. Scotto d'Abusco, A.; Politi, L.; Giordano, C.; Scandurra, R. A peptidyl-glucosamine derivative affects IKK $\alpha$ kinase activity in human chondrocytes. Arthritis Res. Ther. 2010, 12. [CrossRef]

13. D'Adamo, S.; Cetrullo, S.; Panichi, V.; Mariani, E.; Flamigni, F.; Borzì, R.M. Nutraceutical Activity in Osteoarthritis Biology: A Focus on the Nutrigenomic Role. Cells 2020, 9, 1232. [CrossRef] [PubMed]

14. Stoppoloni, D.; Politi, L.; Leopizzi, M.; Gaetani, S.; Guazzo, R.; Basciani, S.; Moreschini, O.; De Santi, M.; Scandurra, R.; Scotto d'Abusco, A. Effect of glucosamine and its peptidyl-derivative on the production of extracellular matrix components by human primary chondrocytes. Osteoarthr. Cartil. 2015, 23, $103-113$. [CrossRef]

15. Committee on Herbal Medicinal Products (HMPC). Community Herbal Monograph on Harpagophytum Procumbens Dc. and/or Harpagophytum Zeyheri Decne, Radix; European Medicines Agency: Amsterdam, The Netherlands, 2008.

16. Dragos, D.; Gilca, M.; Gaman, L.; Vlad, A.; Iosif, L.; Stoian, I.; Lupescu, O. Phytomedicine in joint disorders. Nutrients 2017, 9, 70. [CrossRef] [PubMed]

17. Lim, D.W.; Kim, J.G.; Han, D.; Kim, Y.T. Analgesic effect of harpagophytum procumbens on postoperative and neuropathic pain in rats. Molecules 2014, 19, 1060-1068. [CrossRef]

18. Gagnier, J.J.; Chrubasik, S.; Manheimer, E. Harpgophytum procumbens for osteoarthritis and low back pain: A systematic review. BMC Complement. Altern. Med. 2004, 4, 13. [CrossRef] 
19. Fiebich, B.L.; Fiebich, B.L.; Heinrich, M.; Hiller, K.O.; Kammerer, N. Inhibition of TNF- $\alpha$ synthesis in LPS-stimulated primary human monocytes by Harpagophytum extract SteiHap 69. Phytomedicine 2001, 8 , 28-30. [CrossRef]

20. Akhtar, N.; Haqqi, T.M. Current nutraceuticals in the management of osteoarthritis: A review. Ther. Adv. Musculoskelet. Dis. 2012, 4, 181-207. [CrossRef]

21. Wegener, T.; Lüpke, N.P. Treatment of Patients with Arthrosis of Hip or Knee with an Aqueous Extract of Devil's Claw (Harpagophytum procumbens DC.). Phyther. Res. 2003, 17, 1165-1172. [CrossRef] [PubMed]

22. Chantre, P.; Cappelaere, A.; Leblan, D.; Guedon, D.; Vandermander, J.; Fournie, B. Efficacy and tolerance of Harpagophytum procumbens versus diacerhein in treatment of osteoarthritis. Phytomedicine 2000, 7, 177-183. [CrossRef]

23. Haseeb, A.; Ansari, M.Y.; Haqqi, T.M. Harpagoside suppresses IL-6 expression in primary human osteoarthritis chondrocytes. J. Orthop. Res. 2017, 35, 311-320. [CrossRef] [PubMed]

24. D'Ascola, A.; Irrera, N.; Ettari, R.; Bitto, A.; Pallio, G.; Mannino, F.; Atteritano, M.; Campo, G.M.; Minutoli, L.; Arcoraci, V.; et al. Exploiting curcumin synergy with natural products using quantitative analysis of dose-effect relationships in an experimental in vitro model of osteoarthritis. Front. Pharmacol. 2019, 10, 1347. [CrossRef]

25. Irrera, N.; D’ascola, A.; Pallio, G.; Bitto, A.; Mazzon, E.; Mannino, F.; Squadrito, V.; Arcoraci, V.; Minutoli, L.; Campo, G.M.; et al. $\beta$-Caryophyllene Mitigates Collagen Antibody Induced Arthritis (CAIA) in Mice Through a Cross-Talk between CB2 and PPAR- $\gamma$ Receptors. Biomolecules 2019, 9, 326. [CrossRef]

26. Ferland, C.E.; Beaudry, F.; Vachon, P. Antinociceptive effects of eugenol evaluated in a monoiodoacetate-induced osteoarthritis rat model. Phyther. Res. 2012, 26, 1278-1285. [CrossRef]

27. Di Sotto, A.; Di Giacomo, S.; Amatore, D.; Locatelli, M.; Vitalone, A.; Toniolo, C.; Rotino, G.L.; Lo Scalzo, R.; Palamara, A.T.; Marcocci, M.E.; et al. A polyphenol rich extract from solanum melongena L. DR2 peel exhibits antioxidant properties and anti-herpes simplex virus type 1 activity In Vitro. Molecules 2018, 23, 2066. [CrossRef]

28. Krenn, V.; Morawietz, L.; Häupl, T.; Neidel, J.; Petersen, I.; König, A. Grading of chronic synovitis-A histopathological grading system for molecular and diagnostic pathology. Pathol. Res. Pract. 2002, 198, 317-325. [CrossRef]

29. Schmittgen, T.D.; Livak, K.J. Analyzing real-time PCR data by the comparative CT method. Nat. Protoc. 2008, 3, 1101-1108. [CrossRef]

30. Li, F.; Tang, Y.; Song, B.; Yu, M.; Li, Q.; Zhang, C.; Hou, J.; Yang, R. Nomenclature clarification: Synovial fibroblasts and synovial mesenchymal stem cells. Stem Cell Res. Ther. 2019, 10, 260. [CrossRef]

31. Scanzello, C.R. Role of low-grade inflammation in osteoarthritis. Curr. Opin. Rheumatol. 2017, $29,79-85$. [CrossRef] [PubMed]

32. Honvo, G.; Reginster, J.Y.; Rabenda, V.; Geerinck, A.; Mkinsi, O.; Charles, A.; Rizzoli, R.; Cooper, C.; Avouac, B.; Bruyère, O. Safety of Symptomatic Slow-Acting Drugs for Osteoarthritis: Outcomes of a Systematic Review and Meta-Analysis. Drugs Aging 2019, 36, 65-99. [CrossRef] [PubMed]

33. Mncwangi, N.; Chen, W.; Vermaak, I.; Viljoen, A.M.; Gericke, N. Devil's Claw-A review of the ethnobotany, phytochemistry and biological activity of Harpagophytum procumbens. J. Ethnopharmacol. 2012, 143, 755-771. [CrossRef]

34. Zhang, L.; Feng, L.; Jia, Q.; Xu, J.; Wang, R.; Wang, Z.; Wu, Y.; Li, Y. Effects of $\beta$-glucosidase hydrolyzed products of harpagide and harpagoside on cyclooxygenase-2 (COX-2) in vitro. Bioorg. Med. Chem. 2011, 19, 4882-4886. [CrossRef] [PubMed]

35. Pichersky, E.; Gershenzon, J. The formation and function of plant volatiles: Perfumes for pollinator attraction and defense. Curr. Opin. Plant Biol. 2002, 5, 237-243. [CrossRef]

36. Wenke, K.; Kai, M.; Piechulla, B. Belowground volatiles facilitate interactions between plant roots and soil organisms. Planta 2010, 231, 499-506. [CrossRef]

37. Gfeller, V.; Huber, M.; Förster, C.; Huang, W.; Köllner, T.G.; Erb, M. Root volatiles in plant-plant interactions I: High root sesquiterpene release is associated with increased germination and growth of plant neighbours. Plant Cell Environ. 2019, 42, 1950-1963. [CrossRef]

38. Kriukova, A.; Vladimirova, I. The GC-MS determination of chemical constituents from harpagophytum procumbens dc roots. Technol. Transf. Innov. Solut. Med. 2017, 52-54. [CrossRef] 
39. Fernandes, E.S.; Passos, G.F.; Medeiros, R.; da Cunha, F.M.; Ferreira, J.; Campos, M.M.; Pianowski, L.F.; Calixto, J.B. Anti-inflammatory effects of compounds alpha-humulene and (-)-trans-caryophyllene isolated from the essential oil of Cordia verbenacea. Eur. J. Pharmacol. 2007, 569, 228-236. [CrossRef]

40. Barboza, J.N.; da Silva Maia Bezerra Filho, C.; Silva, R.O.; Medeiros, J.V.R.; de Sousa, D.P. An overview on the anti-inflammatory potential and antioxidant profile of eugenol. Oxid. Med. Cell. Longev. 2018, 2018, 3957262. [CrossRef]

41. Gertsch, J.; Leonti, M.; Raduner, S.; Racz, I.; Chen, J.Z.; Xie, X.Q.; Altmann, K.H.; Karsak, M.; Zimmer, A. Beta-caryophyllene is a dietary cannabinoid. Proc. Natl. Acad. Sci. USA 2008, 105, 9099-9104. [CrossRef] [PubMed]

42. Chicca, A.; Caprioglio, D.; Minassi, A.; Petrucci, V.; Appendino, G.; Taglialatela-Scafati, O.; Gertsch, J. Functionalization of $\beta$-caryophyllene generates novel polypharmacology in the endocannabinoid system. ACS Chem. Biol. 2014, 107, 1499-1507. [CrossRef] [PubMed]

43. Ames-Sibin, A.P.; Barizão, C.L.; Castro-Ghizoni, C.V.; Silva, F.M.S.; Sá-Nakanishi, A.B.; Bracht, L.; Bersani-Amado, C.A.; Marçal-Natali, M.R.; Bracht, A.; Comar, J.F. $\beta$-Caryophyllene, the major constituent of copaiba oil, reduces systemic inflammation and oxidative stress in arthritic rats. J. Cell. Biochem. 2018, 119, 10262-10277. [CrossRef] [PubMed]

44. El-Sheikh, S.M.A.; Abd El-Alim, A.E.A.F.; Galal, A.A.A.; El-Sayed, R.G.; El-naseery, N.I. Anti-arthritic effect of $\beta$-caryophyllene and its ameliorative role on methotrexate and/or leflunomide-induced side effects in arthritic rats. Life Sci. 2019, 233, 116750. [CrossRef]

45. Scanzello, C.R.; Goldring, S.R. The role of synovitis in osteoarthritis pathogenesis. Bone 2012, 51, $249-250$. [CrossRef]

46. Fukuda, S.; Kohsaka, H.; Takayasu, A.; Yokoyama, W.; Miyabe, C.; Miyabe, Y.; Harigai, M.; Miyasaka, N.; Nanki, T. Cannabinoid receptor 2 as a potential therapeutic target in rheumatoid arthritis. BMC Musculoskelet. Disord. 2014, 15, 275. [CrossRef]

47. Marcu, K.B.; Otero, M.; Olivotto, E.; Maria Borzi, R.; Goldring, M.B. NF-кB Signaling: Multiple Angles to Target OA. Curr. Drug Targets 2010, 11, 599-613. [CrossRef]

48. Scotto d'Abusco, A.; Corsi, A.; Grillo, M.G.; Cicione, C.; Calamia, V.; Panzini, G.; Sansone, A.; Giordano, C.; Politi, L.; Scandurra, R. Effects of intra-articular administration of glucosamine and a peptidyl-glucosamine derivative in a rabbit model of experimental osteoarthritis: A pilot study. Rheumatol. Int. 2008, 28, 437-443. [CrossRef]

49. Veronesi, F.; Giavaresi, G.; Maglio, M.; Scotto d'Abusco, A.; Politi, L.; Scandurra, R.; Olivotto, E.; Grigolo, B.; Borzì, R.M.; Fini, M. Chondroprotective activity of N-acetyl phenylalanine glucosamine derivative on knee joint structure and inflammation in a murine model of osteoarthritis. Osteoarthr. Cartil. 2017, 25, 589-599. [CrossRef]

50. Suh, P.G.; Park, J.I.; Manzoli, L.; Cocco, L.; Peak, J.C.; Katan, M.; Fukami, K.; Kataoka, T.; Yun, S.; Sung, H.R. Multiple roles of phosphoinositide-specific phospholipase C isozymes. J. Biochem. Mol. Biol. 2008, 41, 415-434. [CrossRef]

51. Zini, N.; Lisignoli, G.; Solimando, L.; Bavelloni, A.; Grassi, F.; Guidotti, L.; Trimarchi, C.; Facchini, A.; Maraldi, N.M. IL1- $\beta$ and TNF- $\alpha$ induce changes in the nuclear polyphosphoinositide signalling system in osteoblasts similar to that occurring in patients with rheumatoid arthritis: An immunochemical and immunocytochemical study. Histochem. Cell Biol. 2003, 120, 243-250. [CrossRef] [PubMed]

(C) 2020 by the authors. Licensee MDPI, Basel, Switzerland. This article is an open access article distributed under the terms and conditions of the Creative Commons Attribution (CC BY) license (http://creativecommons.org/licenses/by/4.0/). 